\title{
E A JUREMA SE ABRIU TODA EM FLOR: PRÁTICAS E DISCURSOS PARA EFETIVAÇÃO DE DIREITOS HUMANOS NA JUREMA DO ILÈ ASÉ ORISALÁ TALABÍ
}

\author{
Ciani Sueli das Neves ${ }^{1}$
}

DOI 10.26512/revistacalundu.v3i2.27477

\section{Resumo}

A história da sociedade brasileira se confunde com a história das religiões de matriz afro-indígena, uma vez que esta está intrinsecamente ligada ao sequestro dos povos africanos que para cá foram trazidos quando do tráfico negreiro e também da expropriação e massacre desferidos contra os povos indígenas. Nesse âmbito, se constituiu uma relação diaspórica pautada na violência racial, a qual se deparou até os dias atuais com as estratégias de resistência do povo de terreiro como forma de dar continuidade à sua existência nestas terras. Assim, a Jurema surge como religião e passa a intervir na forma de compreensão do mundo dos sujeitos de modo a contribuir com a transcendência de uma forma reducionista de ver o mundo, passando para a compreensão de um fazer baseado nos princípios e valores que viabilizem um mundo pautado nos ideais éticos, epistemológicos e políticos provenientes dos princípios civilizatórios dos povos que a constituem e vivenciam como experiência religiosa e civilizatória.

Palavras-Chave: Jurema. Racismo. Direitos Humanos.

\section{Y EL JUREMA ABRE TODO EM FLOR: PRÁTICAS Y DISCURSOS PARA DERECHOS HUMANOS EFECTIVOS EM EL JUREMA DE ILÈ ASÈ ORISÀLÀ TALABÍ}

\section{Resumen}

La historia de la Sociedad brasileira se confunde con la historia de las religions de la matriz afro-indígena, ya que está intrinsecamente vinculada al secuestro de los pueblos africanus que fueron traídos aquí duurante el comercio de esclavos y también a la expropiación y la massacre contra los pueblos indígenas. En este context, se constituyó una relación diaspórica basada en la violencia racial, que hasta el dia de hoy ha enfrentado las etrategias de Resistencia del pueblo terreiro como uma forma de

${ }^{1}$ FOCCA/UNICAP 
continuar su existencia en estas tierras. Por lo tanto, Jurema emerge como una religion y comienza a intervenir en la forma de entender el mundo de los sujetos para coontribuir a la trascendencia de uma forma reduccionista de ver el mundo, moviéndose a la comprensión de una acción basada en los principios y valores que permiten un mundo basado en los ideales éticos, epistemológicos y politicos que surgen de los principios civilizadores de los pueblos que constituyen y vivien como una experiencia religiosa y civilizadora.

Palabras Clave: Jurema. Racismo. Derechos Humanos.

\section{Introdução}

A religião é um elemento presente na formação das sociedades ao longo do tempo. Disputas políticas e econômicas dão-se respaldadas em argumentos religiosos de diversas denominações, uma vez que as religiões contribuem para a formação do imaginário social e da formação identitária dos sujeitos. Nesse sentido, a religião pode ser um elemento de legitimação do poder hegemônico, que vise subordinar sujeitos, mas pode figurar como um pressuposto de empoderamento à medida que viabiliza reflexões e fortalecimentos subjetivos com o propósito de favorecer a emancipação dos sujeitos.

A religião, portanto, pode assumir o papel de fomentadora de direitos humanos à medida que contribua para a desconstrução de padrões de subalternidades naturalizadas e impostas aos indivíduos. É sob tal aspecto que este trabalho se propõe a discutir o papel da Jurema como religião e sua contribuição para a promoção dos direitos humanos.

A Jurema é uma religião de matriz afro-indígena, com forte influência no Nordeste do Brasil. Utiliza em sua ritualística elementos magísticos, adota a oralidade como forma de transmissão dos saberes e respeita a autonomia de cada casa na realização de seus cultos. O universo da Jurema é bastante diversificado e conta com a colaboração de entidades variadas, desde Exus e Pombagiras a Malunguinho e PretosVelhos, além dos Caboclos. O que permite uma riqueza de elementos bastante significativos que contribuem para um melhor entendimento da diversidade religiosa.

Sob uma perspectiva de fortalecimento dos sujeitos, a Jurema atua de forma a contribuir com o fortalecimento dos sujeitos que procuram por seus socorros, e contribui para a reformulação de um novo modo de compreender o mundo, de modo 
que incide diretamente sobre a maneira de apreender o universo religioso como um espaço de promoção de direitos humanos a partir do entendimento e da atuação de seus adeptos. As reflexões ora propostas serão ilustradas pela Jurema do Ilè Asé Orisalá Talabí, terreiro de religião de matriz africana e afro-indígena que tem uma contribuição bastante significativa no tocante à participação política e educação de seus adeptos e da comunidade de seu entorno com o objetivo de favorecer o fortalecimento das lutas pela implementação dos direitos humanos.

\section{As Religiões de Matriz Afro-Indígena na formação da sociedade brasileira}

A história da sociedade brasileira se confunde com a história das religiões de matriz afro-indígena, uma vez que esta está intrinsecamente ligada ao sequestro dos povos africanos que para cá foram trazidos quando do tráfico negreiro e também da expropriação e massacre desferidos contra os povos indígenas. Nesse âmbito, se constituiu uma relação diaspórica pautada na violência racial, a qual se deparou até os dias atuais com as estratégias de resistência do povo de terreiro como forma de dar continuidade à sua existência nestas terras.

$\mathrm{Na}$ disputa por poder, o Estado brasileiro sempre deixou claro quais contornos definem o seu projeto político de dominação e, para tal, desenvolveu, ao longo dos anos, os mecanismos de controle de poder de forma a permanecer exercendo o domínio sobre os sujeitos subalternizados e assim definindo "quem pode viver e quem deve ser deixado morrer". É nesse âmbito que se pode identificar o cerne de muitas violências praticadas contra o povo de terreiro ao longo do tempo no País. Se, durante a vigência do Código Criminal e do Código de Processo Criminal haviam os crimes relacionados com as práticas referentes às religiões de matriz afro-indígena, à medida que a sociedade vai avançando em conquistas e ampliação de direitos, tal influência deixa nítido o passivo imaginário que se traça ainda nos dias atuais com relação a tais segmentos.

Historicamente o Brasil utilizou-se de mecanismos estatais, ora para criminalizar, ora para perseguir e justificar violências praticadas contra o povo de terreiro sob a alegação de estar defendendo a ordem e os interesses da sociedade de forma mais ampla. Nesse sentido, não há que se falar em liberdade religiosa e laicidade, 
uma vez que a escolha política do Estado brasileiro se dá ao longo do tempo pela hierarquização de religiões, uma vez que "malgrado a primeira Constituição Republicana assegurasse a liberdade religiosa, perdurou a perseguição sistemática às religiões de matriz africana, próprias a negros e pobres” (BRITO, 2016, p. 39), acrescente-se, ainda, as religiões de matriz indígena sob ataques sucessivos, fosse pela perseguição propriamente dita, fosse pela catequização desencadeada até os dias atuais por segmentos de religiões hegemônicas ${ }^{2}$.

Assim, apesar de passados os anos, e sob vigência de uma Constituição tida como democrática, os terreiros de religião de matriz afro-indígena permanecem sob o desafio de lidar cotidianamente com o racismo vigente na sociedade brasileira e, com isso, vêem-se obrigados a buscar mecanismos de autodefesa e apropriação dos mecanismos desencadeados pelo Estado como uma das estratégias de enfrentar o genocídio negro e indígena que atinge de maneira incisiva as formas tradicionais desses sujeitos de se relacionar com o sagrado, uma vez que esta tem sido a realidade da grande maioria dos terreiros no território brasileiro, seja na disputa travada pela manutenção do território ou por outros tipos de confronto, pois de acordo com Brito:

Um dos grandes desafios para os Terreiros urbanos, autênticos 'quilombos', é a crescente perda do seu território, devido às desapropriações pelo poder público, invasões e ocupações irregulares, à especulação imobiliária, ao estelionato na venda de glebas, com imenso prejuízo à mata, ou roça, e às fontes, essenciais ao culto e às obrigações (BRITO, 2016, p. 256).

Entretanto, a luta travada em defesa da territorialidade é um dos desafios que vem se associar a outros que se inter-relacionam, a exemplo das alegações de supostos maus tratos e agressões praticadas ao meio ambiente pelos adeptos das religiões de matriz afro-indígena. Numa nítida demonstração de ignorância acerca dessas religiões, adversários, seja por professarem credos diferentes, em sua maioria neopentecostais, seja por atuarem sob a alegação de defensores do meio ambiente, com ênfase para os protetores dos animais, escolhem tais religiões como alvo de acusações, perseguições e demonizações que colocam em risco a continuidade de suas práticas e a integridade dos espaços sagrados e de seus praticantes. Nessa perspectiva, tem sido comum o

\footnotetext{
${ }^{2}$ Nos tempos de Colônia e Império, os povos indígenas eram submetidos a catequizações advindas de congregações pertencentes à Igreja Católica. Nos dias atuais, o cenário de catequização passou a ser conduzido, majoritariamente, por igrejas protestantes, em sua maioria, de denominações neopentecostais.
} 
ajuizamento de denúncias em que sacerdotes e sacerdotisas de religiões de matriz afroindígena figuram como réus sob a alegação, majoritariamente, de descumprimento das legislações ambientais, colocando, portanto, em risco o interesse da coletividade na garantia de um meio ambiente equilibrado.

É sob tais alegações que os mecanismos jurídicos têm sido utilizados como uma via de criminalização das lideranças de religiões de matriz afro-indígena. Em boa parte dos casos, o Ministério Público tem figurado como o principal agente pugnador pela utilização dos meios jurídicos de criminalização das lideranças de religiões de matriz afro-indígena, ressalte-se que na maioria das vezes sob a alegação de estar defendendo os interesses da sociedade.

Sob outro aspecto, as religiões de matriz afro-indígena constituem-se em alternativas de promoção da dignidade humana à medida que socorrem aos, num dizer de Fanon, condenados da terra, em suas buscas por socorro a questões imediatas seja no âmbito material ${ }^{3}$ seja no âmbito espiritual propriamente dito. Tal característica se faz ainda mais visível nos terreiros de Jurema, tradição religiosa muito presente no Nordeste brasileiro e objeto de estudo do trabalho ora proposto.

\section{Jurema é um pau de ciência que todos querem saber ${ }^{4}$}

A Jurema consiste em uma tradição religiosa de marcante ligação indígena e forte presença no Nordeste brasileiro. Para alguns estudiosos e também muitos praticantes, é definida como Catimbó, termo usado por muito tempo com conotação pejorativa, devido ao uso freqüente de elementos magísticos, por diversas vezes associados com práticas de feitiçaria. Obviamente que tal associação tem relação intrínseca com as práticas de perseguição e demonização realizadas pelos setores dominantes da sociedade desde a colonização do Brasil, forma diuturnamente utilizada para difundir com eficácia a catequização dos diversos povos tradicionais existentes

\footnotetext{
${ }^{3}$ É comum, no cotidiano dos terreiros, as pessoas se aproximarem em busca de um amparo para resolver questões de ordem material, referentes à busca por trabalho, saúde, desequilíbrios financeiros e afetivos, numa proporção muito maior que a busca espiritual, cuja motivação seja uma vivência da religiosidade. Esta termina por se desencadear como uma conseqüência da procura iniciada pelo consulente quando da ida ao terreiro. Nesse sentido, os terreiros terminam por funcionar como grandes pronto-socorros de ordem socioeconômica para a maioria das pessoas que procuram tais espaços religiosos.

${ }^{4}$ Fragmento de toada muito usada nos terreiros de Jurema nos momentos ritualísticos.
} 
nestas terras, fossem os nativos indígenas, fossem os africanos seqüestrados ou ciganos banidos de suas terras originais. A Jurema é, na verdade, uma tradição religiosa de universo amplo, complexo e profundo (LOMI L'ODÓ, sd) cuja importância é traduzida na forma como atua na sociedade, numa perspectiva de viabilizar o acesso a direitos e políticas públicas a partir do fortalecimento do indivíduo enquanto sujeito de direitos e na manutenção das práticas tidas como tradicionais. Segundo Alexandre Lomí L’Odó:

\begin{abstract}
A Jurema Sagrada é considerada pelos juremeiros e juremeiras como a 'religião primaz do Brasil'. Isso se justifica pela presença dos índios e suas práticas religiosas e culturais, antes da chegada dos colonizadores em terras do que hoje chamamos de Brasil. Essa prática foi uma das mais perseguidas entre as religiões tradicionais de terreiro, pois já no século XVIII, foi registrado no Processo 484 - 1741, julho, I, Recife (36 documentos) do Arquivo Histórico Ultramarino - Conselho Ultramarino, a perseguição ao uso da Jurema pelos índios. (L'ODÓ, sd, p. 1085).
\end{abstract}

De acordo com Lodó, os documentos da época constavam de cartas do governador da capitania de Pernambuco ao rei D. João VI fazendo referência ao uso de uma bebida chamada jurema ingerida pelos índios feiticeiros. $\mathrm{O}$ desconhecimento aliado ao racismo estabelece imaginários que resultam no prejuízo das categorias alvo das alegações discriminatórias. É sob tal perspectiva que a Jurema passa a ser conhecida e segue alvo de discriminações ao longo dos séculos.

Entretanto, a Jurema terminou por se constituir em um termo polissêmico, pois nomeia uma árvore, uma bebida, uma tradição religiosa, e todas essas denominações estão associadas e configuram a ligação cosmológica que termina por incidir na ligação dos diversos significados. Segundo Alexandre Lomi L’Odó:

(...) vasto é seu significado, que pode ser uma árvore da família das leguminosas - mimosácea, tendo em localidades diferentes variadas denominações como angico-branco, jurema, juremari, jerema, jeremari, jeroma, jacaré vinhático-de-espinho, tataré, tatané (Argentina), jerumaré, jerumari, curumaré (Pitecolobium tortum), entre outros (L’ODÓ, sd, p. 1087).

E continua:

A Jurema [Mimosa tenuiflora (willd.) Poiret], sinonímia: Mimosa hostilis (Mart.) Benth, M. Nigra J. Huber, M. Cabrera Karsten, ... Antigas Acacia tenuiflora Willd, Acacia hostilys Mart (1), da família 
Mimosaceae, cujos nomes populares podem ser encontrados em diversas áreas do sertão brasileiro, é uma árvore que floresce no agreste e no sertão nordestino, encontrando-se muito facilmente nas caatingas, onde expande-se muito, dominando quase toda vegetação nas regiões em que se encontra (L’ODÓ, sd, p. 1089).

Ainda sobre a Jurema como árvore, prossegue Alexandre Lomí L’Odó:

A Jurema faz parte de uma família de plantas sagradas em todo mundo. $\mathrm{O}$ culto, como o dos egípcios e hebreus, era à acácia nilótica; os hindus, à acácia suma; os árabes, à acácia arábica; os incas, à acácia cebil; os nativos do Orinoco, à acácia niopo (SANTOS, 2007). E, os povos brasileiros, em especial os afro-descendentes dos terreiros de candomblé Jeje-nagô cultuam e mantêm práticas litúrgicas com a acácia amarela, tida como árvore, folha, frutos e flor de Oxum e Oxumarê, usadas em banhos rituais e em cerimônias de sacrifício animal, e ainda dedicam as folhas da Jurema Preta Acácia farnesiana [(L) Wild; Syn.] aos orixás Oxóssi e Ossae, em alguns rituais específicos do candomblé Ketu da Bahia (L’ODÓ, sd, 1089).

Conforme alegado inicialmente, a Jurema constituiu-se em um termo polissêmico, logo, dados os seus diversos significados, compreende também uma bebida produzida pelos indígenas e que segue sendo preparada até os dias atuais para fins ritualísticos. Segundo Sandro Guimarães de Salles:

Há diversos documentos, principalmente a partir do século XVIII, que registram a utilização dessa bebida pelos índios nordestinos no período colonial. Esses documentos aparecem sempre em um contexto de repressão ao seu consumo e assinalam que a bebida era usada em eventos religiosos. A popularidade do seu uso, portanto, é evidenciada em diversos documentos, como o que institui o Diretório dos Índios de Pernambuco, criado pelo Marquês de Pombal, que, como vimos, faz referência direta à jurema, proibindo inteiramente o seu uso (SALLES, 2010, p. 138).

E prossegue:

Hoje, a jurema (bebida) está presente em diferentes contextos, sendo, do mesmo modo, bastante variada a forma de prepará-la. No caso do catimbó de Alhandra, bem como nos atuais cultos umbandizados daquela região, seu significado é eminentemente simbólico. No primeiro, pelo fato de a quantidade de jurema ingerida durante as sessões ser muito pequena. No segundo, pela quase ausência da bebida (SALLES, 2010, p. 140) Mesmo no contexto do Catimbó, o vinho da jurema era consumido em quantidades muito pequenas, geralmente em um cálice, denominado príncipe. Dorinha, neta de Maria do Acais, 
me afirmou que o vinho da jurema durava aproximadamente dois anos, uma vez que se tornava uma quantidade muito pequena de bebida ou, em suas palavras (juntando o polegar com o indicador), "uma coisinha assim de jurema" (SALLES, 2010, p. 140).

De acordo com Sandro Guimarães de Salles, no Centro Espírita do Mestre Zé Pilintra a bebida jurema consiste em uma infusão de jurema, junca, canela, cravo e cachaça, que é servida a algumas entidades e aos presentes (SALLES, 2010, p. 141).

O terceiro aspecto definidor da jurema se dá pela sua caracterização como religião. Nas palavras de Alexandre Lomi L'Odó:

Os juremeiros e juremeiras, hoje, afirmam que a 'a Jurema é religião primaz do Brasil', e que é de "matriz indígena", a religião mais forte historicamente, por sua força de sobrevivência aos processos de atrofiamento teológico, cultural e histórico. Ainda acreditam ser possível um resgate do imaginário mais antigo das práticas indígenas para fortalecer as práticas hoje umbandizadas (L'ODÓ, sd, p. 1094).

Os estudiosos sobre a Jurema afirmam que esta é uma religião que, conforme o seu amplo universo, tem como prerrogativa acolher aos que a ela se chegam, assim, na Jurema, embora seja uma religião cuja base de fé se faz na crença em um Deus único, existe o dinamismo que permite a renovação de suas forças e formas, consistindo-se, assim, em uma vertente religiosa não estática. Segundo Alexandre Lomi L’odó:

"A Jurema é uma religião de princípio xenofílico". Segundo revela o teólogo afro Jayro Pereira de Jesus, em entrevista: "Ela, assim, como as religiões de matrizes africanas, tem essa característica de se fortalecer sem excluir o outro, ou julgar o outro", afirma. Portanto, essa perspectiva é facilmente identificada quando percebemos que na Jurema tem em sua prática religiosa o não-impedimento de adesão de novas "forças" espirituais, rituais etc., como identifica-se na infinita roda das entidades da Jurema, que nunca param de se renovar, com a chegada sempre de novos mestres e mestras e outras entidades (consciências de outras pessoas - os espíritos) nos terreiros. Portanto, ela também não é uma religião estática, nem ritualmente, nem filosoficamente.

A religião da Jurema é baseada na fé em um Deus único aparentemente o mesmo dos cristãos -, mas devemos incorporar o entendimento de que este Deus na verdade pode ser feminino (Deusa) como a Mãe Tamain, dos Fulniô, ou com outros nomes como Pai Tupã. Portanto, sua teofonia se dá pela ingestão da bebida sagrada da Jurema e a manifestação das entidades e divindades cultuadas, além do próprio diálogo, também, como o meio, a natureza. (L'ODÓ, sd, p. 1096). 
A Jurema, portanto, detém um universo complexo, no qual nem o maniqueísmo nem a polarização entre o bem e o mal, o certo e o errado, o pecado são elementos valorativos das práticas de seus adeptos, e sim, a compreensão de que a tudo que se produz há uma consequência, e para tal, é necessário que o indivíduo tenha compreensão de seus atos, palavras e pensamentos.

\section{Quem é filho dessa casa tomba, mas não cai ${ }^{5}$}

A comunidade religiosa Ilè Asè Orisalá Talabí se constitui a partir de um terreiro tradicional de religião de matriz africana e indígena. Nessa casa são realizados os cultos tradicionais de Candomblé e Jurema. No tocante ao Candomblé a casa pertence à tradição nagô, vertente de culto com presença bastante significativa em Pernambuco.

A comunidade foi fundada em 1991, por iniciativa da Iyalorixá Maria da Solidade Sousa França, conhecida como Mãe Dada de Oxalá, cuja história se desenvolve entre as linhas do culto ao orixá e da Jurema, ambos compromissos assumidos desde a sua concepção e honrados a partir do momento em que esta passa a se compreender como sujeito no mundo.

Mãe Dada de Oxalá dedicou sua vida a estruturar a comunidade religiosa da qual era líder juntamente com seu marido, Aguinaldo França, conhecido na comunidade sob o nome de Obá Dodê, cujas ações impactaram a vida da comunidade no entorno do terreiro.

O Ilè Asè Orisalá Talabí localiza-se no bairro de Arthur Lundgren I, na cidade de Paulista - PE, Região Metropolitana do Recife. Situado na periferia da cidade, como é o caso da grande maioria dos terreiros, convive diariamente com os desafios existentes nas regiões em que o Estado não garante as condições básicas de vida à população e/ou apenas chega na condição de Estado punitivo. Sob esse aspecto, o terreiro desempenha o papel de uma espécie de socorro às mais diversas formas de dificuldades enfrentadas pelos moradores da região e por pessoas que vem de outras localidades em busca de um auxílio para os males que afligem o corpo e o espírito.

\footnotetext{
${ }^{5}$ Fragmento de toada utilizada nas giras de Jurema do Ilè Asè Orisalá Talabí quando se faz referência à firmeza e confiança dos adeptos nas entidades da casa.
} 
Os problemas existentes na comunidade nunca foram negligenciados por Mãe Dada de Oxalá, que, como uma matriarca, estava sempre em busca de caminhos e alternativas para viabilizar a promoção da dignidade humana das pessoas de forma ampla. Assim, ela e seu marido construíram pequenas casas no terreno em que está instalado o terreiro, com o intuito de obterem uma renda extra para complementar o orçamento familiar. Entretanto, os relatos dos mais velhos ${ }^{6}$ contam que tais casas serviam, na maior parte das vezes, para abrigar mulheres em situação de violência doméstica, como forma de poderem se proteger com os filhos e saírem da condição de opressão em que estavam inseridas. Mãe Dada era professora, e por tal razão, fundou uma escola em seu terreiro, o que ocasionou um período de muita movimentação na casa e permitiu que ela pudesse compreender outros direcionamentos dados pelas divindades que cultuava. Assim, para além das atividades da escola, eram realizadas no terreiro atividades de formação com as crianças da comunidade e suas respectivas famílias. Desse modo, o terreiro passou a ser um espaço que transcendia a função religiosa. Projetos de intervenção social passaram a ser desenvolvidos de forma a incidir diretamente no cotidiano da comunidade.

Com tal intuito foi criado o Programa Tradição, Cultura e Saúde, que, segundo Aguinaldo Júnior, atual sacerdote da casa, tinha como propósito principal potencializar a multiplicação dos saberes e fomentar as práticas tradicionais e experiências do terreiro no âmbito da religiosidade, da saúde e da cultura. Segundo Pai Junior de Odé $^{7}$ os resultados foram sendo ampliados e consolidados em meio à comunidade:

\footnotetext{
${ }^{6}$ Os membros da comunidade religiosa que detém algum cargo na hierarquia religiosa são chamados de mais velhos pelos membros da casa e pelos visitantes e amigos. Os cargos mais comuns são: Axogum homem a quem é atribuída a função de sacralizar os animais para as divindades/entidades; Ogan - homem com função religiosa também atribuída pelos orixás, podem ser funções específicas como tocar o ilú, ou demais funções atribuídas aos homens que detenham tal função sacerdotal; Ekedy - função atribuída às mulheres cuja atribuição é cuidar dos orixás, podendo ser um orixá específico ou os orixás em geral; Iyabassé - mulher a quem é atribuída a função de cozinhar para os orixás; Essas funções são atribuídas a pessoas não rodantes, ou seja, aquelas que não incorporam divindades; Há, ainda, as funções de mãe pequena e pai pequeno na casa, que são auxiliares da Iyalorixá e do Babalorixá nas funções mais diretas nos rituais da casa. É importante ressaltar que essas definições se aplicam na hierarquia do candomblé, quando se trata de Jurema todas essas pessoas permanecem reconhecidas como mais velhas, uma vez que todas detém sacerdócio cujo exercício dar-se-á de forma mais específica, entretanto, a denominação para o rito da Jurema e/ou da Umbanda é de cambono ou cambona. Para além dessas colocações, também é importante frisar que essas são explicações de forma bem resumida sobre o papel de cada um/ cada uma, pois este trabalho, dadas as limitações de tempo e formato, não seria capaz de explicar detalhadamente a função e a importância de cada uma dessas pessoas para a preservação das práticas tradicionais e funcionamento de um terreiro.

${ }^{7}$ Após assumir a função sacerdotal de Babalorixá, Aguinaldo Júnior passou a utilizar o nome Pai Júnior de Odé, referente à sua titulação sacerdotal e ao orixá ao qual foi consagrado. Sob essa denominação é
} 
Como resultado do plano de ampliação de ações o programa realiza na comunidade Axé Talabí diversas atividades: oficinas de multiplicação dos saberes das ervas, oficinas de culinária Afro-brasileira, a abertura do espaço do Terreiro para vacinações em campanhas nacionais e para cadastramento em programas sociais, a distribuição de cestas básicas, o encaminhamento de crianças para acompanhamentos psicológicos, a criação do grupo de pesquisa, a participação em eventos e abertura de espaços em redes para se falar da importância do terreiro e da manutenção de suas práticas. Além dos próprios acontecimentos realizados através da religiosidade e fé que visa o bem-estar humano. As parcerias aos poucos foram se formando e hoje o Terreiro tem inúmeras atividades que fazem parte do programa Tradição, Cultura e Saúde (Pai Júnior de Odé, 2013).

Outras iniciativas também foram sendo desencadeadas, a exemplo do Núcleo Colaborativo de Produção e Moda, que produz indumentárias utilizadas nos rituais religiosos e também de outras peças voltadas para a comercialização. O Núcleo é conduzido pela Ekedy e estilista Afine Maida, que se dedica à pesquisa e concepção de todo o aparato referente à produção de moda e artesanato.

Uma outra atividade desenvolvida no âmbito do terreiro foi a Roda de Leitura Alamoju, conduzida por Mãe Lu de Iemanjá ${ }^{8}$, atual Iyalorixá da casa. De acordo com Mãe Lu de Iemanjá:

O projeto Roda de Leitura Alamoju nasceu em 2007 quando sentirmos a necessidade de trabalhar com crianças da nossa comunidade e sua adjacência. A ideia era que esta ação social estivesse voltada para promoção e fomento à leitura, o acesso ao Livro e aos saberes tradicionais das brincadeiras lúdicas presentes na comunidade. A necessidade nasceu quando percebemos que em nossa região havia uma carência muito forte referente as políticas de acessibilidade à leitura e ao livro e políticas de valorização do espaço de brincar das crianças. Nosso intuito com a implementação das atividades fora o de poder contribuir para a construção de uma visão mais ampla e contemporânea da criança, afirmando e considerando-as como agentes dinâmicos e ativos da sociedade e não como indivíduos sem conteúdo e visão do mundo. A partir de 2008, após um ano da implementação do projeto, as experiências com este segmento de trabalho foram sendo fortalecidas ainda mais na comunidade. Nosso

conhecido entre os integrantes da comunidade religiosa sob sua responsabilidade e nas relações sóciopolíticas que estabelece no seu dia-a-dia.

${ }^{8}$ Luciany Barbosa é o nome civil da Iyalorixá do Ilé Axé Orisalá Talabí, que após assumir a função sacerdotal que lhe foi atribuída, passou a identificar-se como Mãe Lu de Iemanjá, fazendo referência à função religiosa e ao orixá para o qual foi consagrada. É conhecida pela comunidade religiosa e nas relações sócio-políticas que estabelece cotidianamente pelo nome religioso que adotou. 
principal investimento foi na interação socioeducativa saudável, na afetividade, no acolhimento social e familiar, na segurança em relação à integridade física e afetiva das crianças, na aposta de estímulos significativos e importantes, com mais livros, leitura, brincadeiras, aprendizagem, troca de experiências e troca de saberes. Com a criação deste espaço de saber para as crianças da Comunidade Axé Talabí, o Terreiro, nestes sete anos de projeto, pode trabalhar de forma lúdica diversas temáticas de grande importância para o desenvolvimento educacional e social dos participantes, como as temáticas ligadas à valorização da ancestralidade e da identidade étnica das crianças. São em nossos espaços de leitura, de contos, de teatro, de brincadeiras e de saberes que afirmamos a importância das ações do Projeto Roda de Leitura Alamoju como sendo de grande relevância para a formação de novos leitores, para a inclusão social, e, sobretudo, para a construção da cidadania por meio do Livro, da Leitura e da brincadeira. Hoje os resultados sonhados nos anos de criação deste projeto estão às nossas vistas. Não só as crianças, como também seus pais e todos da comunidade, encontram neste espaço a possibilidade de mudança social através da leitura (Mãe Lu de Iemanjá, 2013).

Todas essas atividades viabilizaram o reconhecimento não só da comunidade local, mas da sociedade pernambucana e brasileira acerca da importância do Ilè Asè Orisalá Talabí como um local de fortalecimento sociopolítico dos sujeitos. De modo que proporcionaram a ampliação de parcerias com organizações da sociedade civil, recebimento de prêmios do Ministério da Cultura e financiamento de ações por meio de convênios e cooperação com instituições da cooperação internacional. O Talabí se constituiu, portanto, em um espaço religioso que contribui para a formação política e social das pessoas, porém é importante ressaltar que sem fazer proselitismo religioso, desafio bastante presente no cotidiano de quem exerce vivências religiosas.

Para além das atividades de intervenção política, Mãe Dada de Oxalá tinha a compreensão de que para o fortalecimento do povo de terreiro era preciso atuar em parceria, assim, ela buscou construir uma relação de aproximação e diálogo do terreiro com diversas organizações da sociedade civil. Era comum a sua presença em reuniões de organizações do Movimento Negro, do Movimento Feminista e a sua participação como uma das fundadoras da Rede de Mulheres de Terreiro de Pernambuco, organização na qual ela assumiu a posição de conselheira religiosa juntamente com outras Iyalorixás das demais tradições de religiões de matriz africana e indígena.

Segundo os relatos dos membros da casa, Mãe Dada fora iniciada também no Culto à Jurema Sagrada, por herança espiritual de sua avó, onde tomou posto de Mestra Juremeira, chefe do culto na liturgia da Jurema Sagrada do Mestre João e da Mestra 
Maria Amélia - Jurema do Rei Salomão. No cotidiano do terreiro, Mãe Dada também trabalhava com a Pomba Gira Sete Poeiras, também conhecida como Cigana Puerê. Os membros da casa que conviveram com Mãe Dada relatam as intervenções da Pomba Gira e do Mestre a quem a sacerdotisa dedicava a sua vida por meio de seus afazeres religiosos.

No dia 04 de maio de 2013 Mãe Dada de Oxalá faleceu, deixando o seu legado para ser continuado por seus filhos biológicos, a quem ela transferiu, ainda em vida, as responsabilidades de Iyalorixá, Babaloríxá e Babakekerê da casa, a fim de que a herança espiritual pudesse ser continuada de acordo com a dedicação com que ela empenhou a própria vida.

Assim, passado o período necessário para cumprimento dos ritos fúnebres e do luto, o terreiro passa a ser conduzido pela Iyalorixá Luciany Barbosa de Sousa, Mãe Lu de Iemanjá; pelo Babalorixá Aguinaldo Barbosa de França Junior - Pai Junior de Odé e pelo Babakekerê $\hat{}^{9}$ Hetonny Faynner de Sousa França - Pai Hetonny de Xangô.

A tradição da comunidade religiosa Oxalá Talabí consiste em transferir a condução da casa por consangüinidade. Sendo assim, os filhos biológicos da matriarca receberam a função de dar continuidade à casa. Em virtude de todos professarem a mesma fé, não há relatos de conflitos por partilha de bens nem interesses que colocassem em risco a manutenção da vivência religiosa.

A partir de então, ocorreram mudanças por determinação do oráculo, no sentido de preservar o legado deixado por Mãe Dada, de forma a salvaguardar a sua memória e assim, garantir a defesa da ancestralidade, princípio tão caro às religiões de matriz africana e indígena.

Durante as segundas e quartas-feiras, no horário noturno, o terreiro realiza atendimentos com consultas na Jurema. Nessa linha religiosa duas entidades prestam atendimentos, a Pomba Gira Cigana Puerê, entidade guia da corrente espiritual vivenciada por mãe Lu de Iemanjá, e o Mestre João das Matas, entidade que incorpora na falange de Malunguinho, sendo guia da corrente espiritual deixada a Pai Júnior de Odé. A jurema enquanto rito religioso na comunidade religiosa em apreço tem uma influência muito forte na vida dos adeptos, seja pela forma como educam as pessoas seja pelos resultados obtidos junto às buscas destes.

\footnotetext{
${ }^{9}$ Babakekerê - homem que recebe o cargo de Pai Pequeno. Auxiliar do babalorixá e da Iyalorixá nas funções ritualísticas e na condução da comunidade religiosa.
} 


\section{Ela é cigana velha, ela é cigana velha da cidade do Egito ${ }^{10}$}

A complexidade das religiões de matriz afro-indígena delineia contornos que não dialogam com a forma tradicional como o conhecimento é produzido nos moldes formais da sociedade. Nesse âmbito, a figura da Pombagira se constitui como um dos arquétipos que afronta toda a constituição de uma sociedade hegemônica em que às mulheres é atribuído o papel de submissão e invisibilidade. É uma entidade feminina conhecida pela sua astúcia em desconstruir os cenários que se apresentam como definitivos, o que dá a ela o reconhecimento popular como entidade poderosa em decorrência de seus feitos, conforme o dizer de Farelli em que "o povo conhece essa entidade pelos apelidos de vencedora de demandas, vencedora de guerras, mirongueira; é considerada mulher perigosa, cheia de artimanhas e dengues" (FARELLI, 2011, p. 26).

A cigana Puerê é também assim reconhecida, como mulher poderosa, vencedora de demandas. Há um outro aspecto acrescido à entidade que a diferencia do imaginário popular destinado à figura da Pombagira, que é o fato de apresentar-se como uma mulher séria, sisuda e de posturas consideravelmente rígidas no tocante à ética e à compreensão do papel das mulheres na sociedade brasileira. É praxe se deparar com a Cigana Puerê orientando as mulheres, sejam filhas da casa, sejam clientes, a se insurgirem contra as situações de dominação e opressão a que estejam submetidas. De forma muito peculiar costuma ressaltar a inadmissibilidade de as mulheres se submeterem a tratamentos degradantes por parte dos homens com quem estas se relacionem e a necessidade em buscar formas de se afirmarem como sujeitos de suas próprias vidas.

Os relatos dos membros mais antigos da casa fazem referência constante à forma como a entidade costumava intervir em situações de violência doméstica, muitas vezes orientando o encerramento do relacionamento violento e conduzindo a vítima a buscar os caminhos viabilizados pelo Estado por meio de políticas públicas. É também comum ouvir-se os relatos dos momentos em que ela incidia para que algum consulente

\footnotetext{
${ }^{10}$ Fragmento de toada cantada na jurema em louvor à entidade Pomba Gira Cigana, qualidade atribuída à Pomba Gira Cigana Puerê, que trabalha na casa ora objeto deste trabalho. "Vou ler a sua sorte, o que passou, passou. Ela é cigana velha, ela é cigana velha da cidade do Egito”.
} 
desesperado por situações de desamparo material viesse a obter êxito na procura de um trabalho ou na satisfação de outra necessidade material que lhe fosse de importância imediata. Tal aspecto dialoga com o papel multifacetado da Pombagira nas razões pelas quais são procuradas, nas palavras de Monique Augras:

\begin{abstract}
Basicamente, as solicitações podem ser agrupadas em duas categorias de pedidos, de ajuda ou de demanda. A Pomba Gira Cigana, por exemplo, encarrega-se de resolver casos na Justiça, Maria Padilha atende problemas da vida conjugal, Pomba-gira Rainha lida com casos de amor, Rosa Caveira atende pedidos relativos a doenças materiais e espirituais (Teixeira Neto, p. 55). Outras, como Maria Molambo, são especialistas em solucionar casos de inveja, mas a impressão que se tem, ao percorrer a literatura especializada, é que praticamente todas atendem tanto às pessoas que querem ser ajudadas quanto às que desejam prejudicar alguém (AUGRAS, 2000, p. 36).
\end{abstract}

Entretanto, faz-se necessário dizer que a responsabilidade pelas consequências dos pedidos realizados à Pombagira cabe a quem realiza o pedido, de forma que a entidade que presta o atendimento é apenas o canal para externalização da conduta do indivíduo que a procura. No tocante à Pomba Gira Cigana Puerê da casa ora apresentada é desconhecida qualquer situação em que algum sujeito a tenha procurado com a perspectiva de prejudicar alguém e tenha obtido êxito em seu pedido ${ }^{11}$. Ainda sobre o alcance dos trabalhos de Pombagira, Augras continua:

Chama a atenção o fato de que, embora a representação da Pomba-gira enfatize seus aspectos de mulher sexualmente ativa, a maioria dos trabalhos realizados por ela são vinculados a temas de morte, com forte predomínio de despachos realizados em cemitério. São os casos de Rosa Caveira (que trabalha sob as ordens diretas de Omulu, dono do cemitério na umbanda), Pomba-gira das Sete Encruzilhadas, Pomba-gira do Cruzeiro, da Porteira, da Calunga (que é o nome do cemitério entre os adeptos), e Maria Padilha. O culto a esta última tem-se desenvolvido de tal maneira que chega às vezes a ser considerada uma entidade à parte, separada da Pomba-gira (AUGRAS, 2000, p. 37).

Assim, a ideia de que a Pombagira é uma entidade resumida ao papel da sexualidade extrapolada pode ser identificada como um dos aspectos, e não o único, atribuído à entidade e à sua forma de atuação no espaço do terreiro. E, nesse sentido,

11 Durante o período de observação nas atividades da casa e das conversas empreendidas com os membros da casa não foi identificada nenhuma referência a ações com o objetivo de prejudicar alguém. Em muitos casos foi observado o desfazimento de feitiços praticados contra pessoas que estavam tendo suas vidas prejudicadas e foram ao terreiro em busca de um auxílio. 
não se busca aqui fazer referência ao entendimento moralista da necessidade de se subjugar a Pombagira aos desígnios de controle sobre a entidade e, consequentemente, sobre a sexualidade feminina, uma vez que segundo Augras:

A figura da Pomba-gira, ao mesmo tempo que afirma a realidade da sexualidade feminina, devolve-a ao império da marginalidade. (...) Sabe-se, desde Douglas (1976), que todas as margens são perigosas e também carregadas de imenso poder. Pomba-gira, rainha da marginália, tem sua morada no corpo das mulheres, nos lugares de passagem de um ponto para outro ou deste mundo para além (AUGRAS, 2000, p.40).

Nesse sentido, a imagem de Pombagira para além de suas ações realizadas no âmbito da relação espiritual é um símbolo de afirmação da liberdade e da autonomia feminina como formas de fortalecimento das mulheres e do enfrentamento do patriarcado.

\section{Malunguinho ${ }^{12}$ tá de ronda ${ }^{13}$ !}

João das Matas é o nome do mestre de Jurema que atende no Ilè Asè Orisalá Talabí. É uma entidade integrante da corrente de Malunguinho, conhecido como o último Malunguinho, liderança do quilombo do Catucá, capturado e executado pelas tropas imperiais na zona rural de Abreu e Lima (PE), no ano de 1835. O quilombo do Catucá constitui-se uma referência para os juremeiros e para a afirmação da memória pernambucana no tocante às lutas contra a escravidão no Brasil, numa perspectiva

\footnotetext{
12 Segundo Alexandre Lomi Lodó: o título honorífico Malunguinho, que era dado aos líderes do Quilombo do Catucá (na primeira metade do século XIX em Pernambuco) vem do possível vocábulo Malungo do tronco lingüístico kimbundo (Bantu), que significa amigo, companheiro, camarada ou companheiro de bordo e ainda irmão de criação; nome com que os escravizados africanos tratavam seus companheiros de infortúnio nos navios negreiros e nas senzalas. Possivelmente para uma etnia Bantu, segundo Victor Cajuganga, o sufixo "inho" colocado ao final do termo Malungo, antroponimicamente, em lato sensu, dentro da perspectiva de hipocorístico africana, não significa um diminutivo carinhoso, como é típico no nordeste do Brasil, mas sim conota grandeza e poder, notoriedade e transcendência. Quanto menor a palavra para determinar o título de um líder, ou um diminutivo, mais esta agrega força contexto e méritos. Malunguinho era o possível título genérico para as lideranças no quilombo do Catucá, e também é o líder quilombola que "baixa" nos terreiros de Jurema, foi o líder (líderes) negro/índio que revolucionou e marcou a história da luta por liberdade do povo negro e indígena do Catucá (LODÓ, 2016, p. 26).

13 Toada de Jurema entoada na louvação a Malunguinho, geralmente usada para iniciar os ritos de invocação de Malunguinho. "Malunguinho ta de ronda quem mandou foi Jucá, Malunguinho tá de ronda que a Jurema manda."
} 
bastante distinta do modelo tradicional de quilombo de que se tinha conhecimento.

Segundo Marcus J. M. de Carvalho:

\begin{abstract}
Logo para começar, o quilombo de Malunguinho - o espaço insurreicional mais importante da província - não estava isolado na cidade. Muito pelo contrário, Pernambuco no século XIX, era uma província muito diferente daquela da época do quilombo dos Palmares. Não havia como evitar contato com o Recife. Em que pese a sua essência africana, o quilombo da floresta do Catucá não era uma tentativa de reprodução de alguma sociedade africana, mas um fenômeno americano, híbrido, uma linha de combate contra o status quo, que envolvia gente de diferentes procedências étnicas e histórias de vida. Palmares foi uma tentativa de formação de uma sociedade alternativa. O Catucá tentava isso como ideal, mas a sua posição precária impelia seus habitantes a viverem de roubos, caça, agricultura de subsistência, além da prática de algum comércio e contrabando. Grande parte de suas vítimas eram as boiadas e mascates em geral que levavam coisas do interior para a cidade e vice-versa. Ao contrário dos palmarinos, a situação dos quilombolas do século XIX não permitia isolamento. $\mathrm{O}$ pressuposto para sua existência era a cooperação de pessoas de fora do quilombo (CARVALHO, 2010, p. 180).
\end{abstract}

Assim, após a sua destruição física e execução de suas lideranças, com o advento e popularização da Jurema como religião de matriz indígena, o quilombo do Catucá passou a ser um referencial de resistência para os adeptos da referida tradição religiosa. Malunguinho, por sua vez, foi incorporado como entidade integrante do panteão da Jurema Sagrada e passou a trabalhar em terreiros de matriz afro-indígena sob as mais diversas formas de atuação, sendo reconhecido como uma importante entidade no âmbito de tal segmento religioso. Segundo Marcus J. M de Carvalho:

Depois que tudo acabou, Malunguinho entrou na cultura popular, tornando-se uma entidade no culto da Jurema Sagrada. Entidade poderosíssima, a única que se apresenta como caboclo, mestre ou exu. Subir ao panteão das divindades é talvez a maior homenagem que um povo pode prestar aos seus heróis (CARVALHO, 2010, p. 189).

$\mathrm{O}$ reconhecimento de Malunguinho como entidade do panteão da Jurema Sagrada também é referido por Alexandre Lomi Lodó, que ressalta a sua importância simbólica:

Em Pernambuco, Malunguinho "congregou em si próprio" as duas dimensões do imaginário: o tempo histórico da vida material (que foi continuado no tempo religioso mítico cosmogônico da divindade) e sua prática religiosa/sagrada e tradicional dentro dos terreiros, afinal, 
ele (ou eles) é o único líder quilombola da história do Brasil que virou divindade para os povos tradicionais, "baixando" nos templos de fé afro-indígena (L’ODÓ, 2016, p. 22).

E continua:

Malunguinho é uma divindade na Jurema Sagrada. Sem ele os rituais não podem acontecer com segurança. Ele é o guardião e vigia protetor da Jurema. Para falarmos de Malunguinho, temos antes que entender que ele e sua estrutura de universo e suas narrativas de significação simbólica e mitológica que encerram suas verdades cuja memória se perdeu no tempo e se preservou na oralidade do povo de terreiro têm hoje concreta prática cultural entre os juremeiros e juremeiras. Fala-se muito do termo "ancestral divinizado" no Candomblé. No entanto, também existem no Brasil personagens históricos negros/indígenas que ascenderam ao altar das divindades no imaginário religioso e na luta pelo seu povo. Um destes é Malunguinho, conhecido também como o "Reis das Matas". Ele é verdadeiro no dia a dia dos terreiros, convivendo no cotidiano destes com plena participação na vida de seus discípulos (L'ODÓ, 2016, p. 26).

É sob a perspectiva de agir diretamente no cotidiano de seus discípulos que Malunguinho é procurado nos terreiros. No Talabí é comum a sua procura para resolver questões difíceis ligadas ao acesso a direitos. Os exemplos variam desde uma jovem que perdeu o financiamento estudantil e buscou a intervenção de Malunguinho para conseguir voltar à faculdade, obtendo êxito no pleito, a uma mulher que precisava vender um terreno irregularmente ocupado por um antigo vizinho e que aguardava há mais de 10 anos por uma decisão judicial, até um jovem professor, que desempregado, restou-lhe o comércio informal como alternativa de subsistência. Em todos esses casos Malunguinho atuou de forma a reverter as situações de desesperança das pessoas e elas foram fortalecidas para buscar os meios convencionais de acesso às políticas públicas. Em todas as situações citadas, as pessoas envolvidas atribuem a Malunguinho a resposta positiva a seus pleitos, afirmando que haviam tentado por diversas vias em momentos anteriores e nunca conseguiram alcançar respostas positivas. Algumas afirmaram até terem presenciado manifestações da divindade em determinados momentos em que estavam seguindo as suas orientações para alcançar o objetivo que buscavam.

Nesse âmbito é possível afirmar que a figura de Malunguinho está para além do universo sagrado do terreiro, de modo a traçar elo de ligação entre o sagrado e a realidade material. De acordo com Alexandre Lomi Lodó: 
No ethos do povo da Jurema, os significados habituais de sagrado e profano não se aplicam de forma simples. No dia a dia deste povo, é normal se relacionar com o sagrado em todos os momentos e em quase tudo que se faz sem necessariamente estar ligado a um espaço sagrado ou ao imaginário de sagrado (tocado só em momentos litúrgicos sacros). As entidades e divindades vivem com as pessoas e estão presentes em todos os momentos e em harmonia com o cotidiano, ajudando ou atrapalhando de forma geral. Esta cosmovisão nos possibilita pensar mais sobre como há alteridades religiosas nas culturas tradicionais de terreiro que vão além do senso comum do sagrado e profano que estão supostamente divididos, separados. No caso do imaginário teológico da Jurema, estes dois universos estão juntos e são inseparáveis. Um bom exemplo é ver como os juremeiros e juremeiras se divertem em um momento de beberagem no final de semana em suas casas ou na praia e, mesmo assim separam o copo de cerveja da entidade mestre de Jurema ou mesmo uma pombojira simbolizando um ato de respeito e oferenda sagrada (LODÓ, 2016, p. 27).

Tais alegações apontam para a compreensão dos caminhos que a religião passa a desenhar na vida dos sujeitos, sobretudo, considerando o potencial de transformação na percepção política das pessoas e de como essas podem reverter a condição em que estejam inseridas no mundo. Segundo Eliane Caloy Bovkalovski Souza:

A religião é uma forma de o homem expressar-se, entender e mostrar seu mundo ao outro; tem no culto um ponto de sustentação, porque faz parte de um grupo que compreende com ele os conceitos sobre o sagrado. Esse homem não está só (SOUZA, sd, p. 14).

E continua:

O homem que crê, no contato com o sagrado sofre transformações e altera o ambiente que o cerca, pois ele não é somente alguém que descobriu novas verdades, como também é um ser que pode mais, inclusive no que diz respeito à violência e à guerra, pois o conflito político assume, muitas vezes, uma dimensão religiosa (SOUZA, sd, p. 15).

Malunguinho é, portanto, a figura situada nesse lugar decorrente de outro mundo e que dá ao ser humano que com ele se relaciona o sentido de sustentação, o saber-se não estar só, no dizer de Michelle Gonçalves Rodrigues "a religião é uma linguagem de compreensão sobre o mundo, um fato social total em termos maussianos" (2013, p. 268).

Nesse âmbito, Malunguinho como divindade proporciona aos adeptos da Jurema a possibilidade de absorver a religião como mecanismo de compreensão do mundo e 
afirmação dos direitos humanos a partir de suas experiências de subalternidade. Para Camilo de Lélis Diniz de Farias:

O sujeito subalterno é aquele que, consciente da sua condição política, cultural e epistemológica e da fragilidade da estrutura que lhe dá legitimidade, reconhece a si próprio e a seus semelhantes, articulandose pela superação destas condições degradantes e pela sua emancipação. A luta por direitos destas minorias é, sobretudo, uma demanda pelo reconhecimento da sua própria condição humana, requisito único, em uma ordem verdadeiramente universal, para a titularidade e exercício de direitos, cuja multiplicação se deu, também, justamente pelo reconhecimento das particularidades que os seres humanos têm em si (FARIAS, 2016, p. 119).

E continua:

O juremeiro é, de fato, um sujeito subalterno, e que, na imposição de uma condição desfavorável, constituiu-se como vítima de uma estigmatização - predomínio das características avaliadas negativamente sobre as demais - e, ainda, que a concepção tradicional dos direitos humanos e da cidadania, de cuja concepção os sujeitos subalternos não participaram, não é suficiente para promover uma verdadeira inclusão destes em uma vida política ativa. Para este problema, a solução é a autoconscientização e a luta por uma cidadania insurgente que reforme criticamente as próprias estruturas políticas e jurídicas das sociedades políticas, num verdadeiro processo de refundação dos Estados e reinvenção dos direitos humanos (FARIAS, 2016, p. 120).

Malunguinho é uma divindade com entendimento excessivamente crítico ao Estado, seja pela sua constituição político-jurídica, seja pela sua forma hegemônica de estruturar as relações sociais, entretanto, a forma como atua no atendimento das demandas de quem procura o seu trabalho, a maneira como orienta o modo de vida de seus discípulos, o rigor ético que exige dos adeptos da Jurema associado ao reconhecimento identitário, direcionam-no para o seu reconhecimento como promotor de direitos humanos, uma vez que todas as suas ações resultam na promoção da dignidade da pessoa humana, ainda que por vieses não convencionais para o modelo de sociedade vigente no Brasil.

\section{Os portões da Jurema se abriu, senhores mestres vai fechar!}

No sentido de concluir este trabalho, porém sem encerrar os estudos e reflexões acerca das religiões de matriz afro-indígena, utiliza-se aqui, ainda, da referência ao 
lugar simbólico e material que a Jurema ocupa na vida de seus adeptos e, consequentemente, nos resultados que forja.

A Jurema, dentro da sua polissemia, é referenciada, neste trabalho, primordialmente, sob a sua caracterização de religião tradicional de terreiro. As suas formas características de práticas baseadas na oralidade, no uso de elementos da natureza e magísticos, e a crença nas entidades que são cultuadas para o seu desenvolvimento confirmam o seu reconhecimento enquanto prática religiosa.

Entretanto, o reconhecimento enquanto religião não garante à Jurema que seja professada livremente pelos seus fiéis, sendo, constantemente, alvo de ataques provenientes de intolerância e racismo religiosos. Uma vez que se constitui como uma religião de subalternizados, seja pela elevação de sujeitos marginalizados ao longo da história ao patamar de entidades e guias espirituais, seja pelos sujeitos que, majoritariamente, procuram por seus socorros, tendo em vista serem aqueles a quem o Estado não chega pela efetivação de direitos, a Jurema é, ao mesmo tempo, socorro e alvo de toda sorte de violências.

Apesar das relações ambíguas a que historicamente são submetidas às religiões de matriz africana e afro-indígena no Brasil, a Jurema é um universo de encantamentos, mas também de acolhimento de sujeitos desesperançosos, de socorro material, e de promoção de direitos humanos. Seja por meio dos socorros materiais a partir de doações de alimentos, roupas, material escolar, recursos financeiros, seja pela escuta atenciosa dos problemas relatados pelos adeptos e consequente orientação na busca por resolução do conflito e fortalecimento da autoconfiança da pessoa em atendimento para que ela própria consiga visualizar as formas possíveis de solução aos seus dramas particulares.

É sob tal perspectiva que a Jurema do Ilé Asé Orisalá Talabí atua no sentido de conduzir de maneira concreta a relação entre orientação religiosa e vida material no sentido de viabilizar em seus adeptos o entendimento dos mecanismos de acesso aos direitos sem se dissociar da relação com as entidades condutoras, a fim de que seja possível viabilizar a compreensão da indissociabilidade entre vida espiritual e vida material para os adeptos da Jurema como vivência religiosa.

Assim, a atuação de entidades como Pombagira e Malunguinho nesse cenário, entidades que permeiam um universo marcado pelas disputas políticas nas religiões, evidenciam o caráter epistemológico e decolonial do qual a Jurema, enquanto forma de vida de povos e comunidades tradicionais, é constituída. Sua proposta metodológica, 
política e ética transcende os limites da ética colonialista, constituída por uma formapensamento branca, eurocêntrica, burguesa, para afirmar o poder de organização e refundação de saberes advindos de sujeitos historicamente concebidos como marginalizados em meio à sociedade hegemônica.

Nesse âmbito, a Jurema é, portanto, um caminho para a reinvenção dos direitos humanos, voltada para a emancipação dos sujeitos subalternizados a partir das construções históricas, geográficas e políticas que considerem as suas especificidades e a indispensabilidade de tal entendimento para a garantia e efetivação dos direitos humanos destes, de forma a tornar possível uma sociedade verdadeiramente plural e respeitosa das diversidades, condições, estas, indispensáveis para a promoção da democracia, da igualdade como valor e da paz. É sob tal compreensão que a Jurema se afirma como tradição religiosa e contribui para a formulação de um novo modelo de sociedade.

\section{Referências Bibliográficas}

ASSUNÇÂO, Luiz Carvalho. “A Tradição do Acais na Jurema Natalense: memória, identidade, política". Revista Pós-Graduação em Ciências Sociais, v.11, n. 21, jan/jun. 2014.

ASSUNÇÂO, Luiz Carvalho.O Reino dos Mestres: a tradição da jurema na umbanda nordestina. Rio de Janeiro: Pallas, 2010.

AUGRAS, Monique. "De Iyá Mi a Pomba Gira: transformações e símbolos da libido". In: MOURA, Carlos Eugênio Marcondes de. Candomblé: religião do corpo e da alma: tipos psicológicos nas religiões afro-brasileiras. Rio de Janeiro: Pallas, 2000.

BRITO, Lidivaldo Reaiche Raimundo. A Proteção Legal dos Terreiros de Candomblé: da repressão policial ao reconhecimento como patrimônio histórico-cultural. Salvador: Kawô-Kabiyesilé, 2016.

CARNEIRO, João Luiz. Religiões Afro-Brasileiras: uma construção teológica. Petropólis/RJ: Vozes, 2014. 
CARVALHO, Marcus J. M. de. Liberdade: rotinas e rupturas do escravismo no Recife, 1822 - 1850. 2a . ed. Recife: Ed. Universitária da UFPE, 2010.

FARELLI, Maria Helena. Pomba Gira Cigana: magias de amor, sorte, sonhos, reza forte, comidas e oferendas. Rio de Janeiro: Pallas, 2011.

FARIAS, Camilo de Lélis Diniz de. Salve a Jurema Sagrada! Identidades e direitos humanos na religiosidade afro-ameríndia em Campina Grande/PB. Dissertação (Mestrado) - UFPB/CCHL. João Pessoa, 2016.

L'ODÓ, Alexandre Alberto Santos de Oliveira L'Omi. “Teologia da jurema, existe alguma?". V Colóquio de História: Perspectivas históricas: historiografia, pesquisa e patrimônio. Recife: 16 a 18 de setembro de 2013.

L’ODÓ, Alexandre Alberto Santos de Oliveira L’Omi. “Malunguinho: um pressuposto juremológico de história oral”. III Congresso Nordestino de Ciências da Religião e Teologia: Devoções religiosas e pluralismo cultural. Recife: 08 a 10 de setembro de 2016.

RODRIGUES, Michelle Gonçalves e CAMPOS, Roberta Bivar Carneiro. "Caminhos da Visibilidade: a ascensão do culto a jurema no campo religioso de Recife". Revista Afro-Ásia, 47 (2013), $269-291$.

RODRIGUES, Michelle Gonçalves. Da Invisibilidade à Visibilidade da Jurema: a religião como potencialidade política. Tese (doutorado). Universidade Federal de Pernambuco. CFCH: Programa de Pós-Graduação em Antropologia. Recife: 2014.

SALLES, Sandro Guimarães de. À Sombra da Jurema Encantada: mestres juremeiros na umbanda de Alhandra. Recife: Editora Universitária da UFPE, 2010.

SOUZA, Etiane Caloy Bovkalovski. "O Homem, a religião e a apropriação política do sagrado". Revista de Relações Internacionais no Mundo Atual. s/d. 
Revista Calundu - Vol.3, N.2, Jul-Dez 2019

Recebido em: 04/10/2019

Aceito em: 23/10/2019 